Primljen / Received: 23.8.2012. Ispravljen / Corrected: 1.9.2013.

Prihvaćen / Accepted: 10.9.2013.

Dostupno online / Available online: 10.10.2013.

\section{Office building maintenance: Cost prediction model}

\section{Authors:}

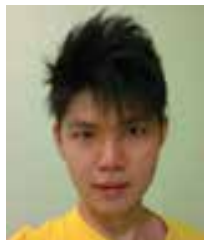

Cheong Peng Au-Yong, PhD. CE University of Malaya

Faculty of Built Environment

auyongcp@um.edu.my

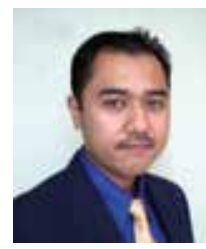

Assoc.Prof. Azlan Shah Ali, PhD. CE

University of Malaya

Faculty of Built Environment

asafab@um.edu.my

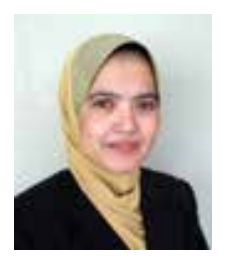

Faizah Ahmad, PhD. CE

University of Malaya

Faculty of Built Environment

faiz@um.edu.my

\section{Cheong Peng Au-Yong, Azlan Shah Ali, Faizah Ahmad}

\section{Office building maintenance: Cost prediction model}

Building maintenance costs are increasing rapidly due to poor maintenance in the past. In this paper, attempts are made to identify the characteristics of scheduled maintenance. It has been established that the characteristics of scheduled maintenance always affect the cost performance. Therefore, this research aims to establish their relationships. Then, regression model is produced for maintenance prediction purposes. The triangulation approach that includes literature review, questionnaire survey, and interviews, has been adopted for data collection. Consequently, the regression model can be adopted by practitioners.

\author{
Key words: \\ office building, scheduled maintenance, cost performance, regression model
}

Prethodno priopćenje

\section{Cheong Peng Au-Yong, Azlan Shah Ali, Faizah Ahmad}

\section{Održavanje poslovnih zgrada: model predvidanja troškova}

Troškovi održavanja zgrada naglo rastu u slučaju neprimjerenog održavanja u prethodnom razdoblju. U ovom radu određene su karakteristike planiranog održavanja. Ustanovljeno je da karakteristike planiranog održavanja uvijek utječu na troškove te je nužno uspostaviti njihov odnos. Za predvidanje održavanja izrađen je regresijski model, a za prikupljanje podataka usvojen je triangulacijski pristup koji uključuje pregled literature, anketiranje putem upitnika i usmeno anketiranje. Zaključeno je da se uspostavljeni regresijski model može koristiti u praksi.

Ključne riječi:

poslovna zgrada, planirano održavanje, učinak troškova, regresijski model

Vorherige Mitteilung

Cheong Peng Au-Yong, Azlan Shah Ali, Faizah Ahmad

\section{Instandhaltung von Bürogebäuden: Model für die Kostenvorhersage}

Kosten der Gebäudeinstandhaltung können Aufgrund unzureichender Instandhaltung in der Vergangenheit schnell ansteigen. Daher strebt diese Arbeit an, die Merkmale geplanter Wartung zu identifizieren. Den Feststellungen folgend, beeinflussen die Eigenschaften geplanter Instandhaltung in jedem Fall die Kostenleistung. Daher befasst sich diese Arbeit mit dem Ziel, entsprechende Zusammenhänge aufzustellen. Folglich ist ein Regressionsmodel für die Wartungsvorhersage eingeführt. Für die Datenerfassung ist ein Triangularverfahren, das einen Literaturüberblick, Umfragen und Interviews umfasst, angewandt worden. Dementsprechend kann das Regressionsmodel von Anwendern in der Praxis eingesetzt werden.

Schlüsselwörter:

Bürogebäude, geplante Instandhaltung, Kostenleistung, Regressionsmodel 


\section{Introduction}

Building maintenance is the combination of technical and administrative actions aimed at ensuring that the items and elements of a building are in an acceptable condition to perform their required function. In order to implement or perform the tasks of building maintenance efficiently, a proper building maintenance management is necessary.

According to BS3811, building maintenance can broadly be subdivided into two main categories: planned maintenance and unplanned maintenance [1]. The planned maintenance consists of predetermined tasks that are well organised and performed in advance. The maintenance actions either reduce or prevent damage to components or items. On the other hand, unplanned maintenance activities are carried out in the event of emergency or contingency maintenance, without any predetermined plan. The maintenance actions are carried out after failure or damage has been detected.

In fact, the planned maintenance, rather than the unplanned maintenance, is considered to be the major activity in the sphere of building maintenance. Otherwise, frequent incidences of breakdown or downtime could occur, and high maintenance costs could be incurred for repair and replacement works needed in the scope of unplanned maintenance [2]. Thus, the unplanned maintenance should be minimised in order to achieve an optimum maintenance expenditure situation.

Since several strategic management options are available, and as many alternative decisions should be considered to maintain a building in a proper condition, the study on maintenance strategies is necessary to control the maintenance performance, maintenance cost in particular [3]. In this research, characteristics of scheduled maintenance are studied and reviewed because this type of maintenance is nowadays widely used and accepted. This is followed by the study of relationship between characteristics of scheduled maintenance and cost performance.

\section{High-rise office building}

In Malaysia, a high-rise building is defined as the building that has more than 7 floors (or the top floor of building is more than 60 feet above the ground level) [4]. This definition is in accordance with the Uniform Building By-Laws passed in 1984. The maintenance of buildings in Malaysia has recently become an issue of a growing significance, and several studies and research efforts have been made about the facilities management and maintenance management functions of high-rise office building.

Office buildings always have their own maintenance management teams that maintain such buildings in good operating condition. These teams are managed by maintenance or building managers [5]. Basically, the services provided by building managers in office buildings are cleaning, landscaping, general maintenance, lighting, heating, ventilation, and air conditioning (HVAC), lift or escalator maintenance, mechanical and electrical installations, sanitary and plumbing services, access, signage, parking, and other [6]. These services are significant office building systems that have to be properly covered by maintenance management, as they provide functionality, safety, health, and comfort to building users in the scope of their daily working activities.

Unfortunately, it was established during the building satisfaction survey that most of the building users are not satisfied with building services provided to them [5]. This is mainly due to the issues such as the lack of maintenance staff, lack of expertise, lack of tools and technology, insufficient budget allocated to maintenance, inappropriate maintenance strategies, and so on. These issues occur more often in highrise office buildings than in medium-sized buildings, as they are frequently equipped with more sophisticated systems such as fire detection and protection systems, central heating, ventilation and air conditioning systems, escalators and others [7].

Therefore, this research focuses on the causes of building users' dissatisfaction in high-rise office buildings. In other words, the characteristics of the maintenance strategy (scheduled maintenance), as related to maintenance performance, are examined.

\section{Characteristics of scheduled maintenance}

Scheduled maintenance is defined as the preventive maintenance that is carried out in accordance with criteria such as the predetermined intervals of time, number of operations, mileage, etc., so as to ensure that such components remain in good condition [1, 3, 8, 9]. Generally, maintenance activities conducted at fixed time intervals are meant to reduce the probability of failures and breakdowns [10]. However, some researchers argue that scheduled maintenance is not cost effective, as components are often replaced regardless of their condition. It is indicated in literature that the performance of scheduled maintenance activities relies on the following criteria:

\subsection{Skilled labour}

Since scheduled maintenance is carried out in fixed time intervals, it does require permanent maintenance personnel or technicians to perform the tasks. Commonly, the organisation allocates different salaries for the maintenance personnel based on their level of competence. In fact, qualification of the maintenance labour force is an important factor that affects the maintenance outcome [11]. For instance, some of the scheduled maintenance works are determined by experienced and skilled technicians, who observe the wear and tear of relevant parts or components. The technicians should not limit their capability to mere replacing and overhauling system components, but they must also be capable of identifying the 
need for scheduled maintenance. Furthermore, scheduled maintenance activities are labour intensive [3]. Thus, skilled labour is one of the main characteristics to be considered for implementation of scheduled maintenance, which includes:

- Skill and knowledge of labour

- Number of labour

\subsection{Spare parts and materials}

Spare parts and materials are much more required for scheduled maintenance, compared to other maintenance strategies [3]. Some parts of building systems or services need to be replaced with new ones in fixed intervals as determined in the schedule maintenance program, regardless of whether these items are damaged or not. Thus, an accurate spare parts identification and stocking is valuable in controlling and reducing the operation and maintenance costs [12]. In addition, the quality of spare parts and materials is always significant for maintenance performance [13]. Thus, the selection of spare parts and materials should not only focus on cost saving, as the quality of spare parts and materials is an another essential aspect to be taken into consideration. In this research, spare parts and materials cover:

- Level of stock of spare parts and materials

- Quality of spare parts

\subsection{Predetermined maintenance intervals}

Maintenance intervals are of critical significance for the outcome of maintenance activities. Failure to perform maintenance tasks at the right time may cause further damage to system components [14]. Meanwhile, it is argued that the scheduled maintenance programs might not be able to avoid the risk of failure of system components before the fixed replacement time [15]. This problem occurs due to unknown condition of the system components. Hence, an adequate maintenance interval must be identified and implemented so as to enhance the effectiveness of scheduled maintenance activities. Therefore, the criterion of predetermined interval of maintenance includes the length of the predetermined maintenance interval.

\subsection{Maintenance and failure downtime}

Since the scheduled maintenance is not able to prevent the risk of failure, the downtime and cost allocation for maintenance and failure should be taken into account when defining the maintenance approach [15]. A breakdown can sometimes cause collateral damage in a particular system [16]. In this respect, an additional downtime and cost will be incurred for failures that occur before the predetermined maintenance time. Hence, the amount of downtime for maintenance and failure must be taken into consideration for the planning and execution of scheduled maintenance activities.

\section{Maintenance performance}

In management, the development of performance measurement is to improve quality and service, as well as meeting cost parameters [17]. Measurement of maintenance performance is an assessment that helps to identify the strengths and weaknesses of maintenance activities. In addition, the result of performance measurement points to the effectiveness of the existing strategy. Consequently, the management team is able to plan and make appropriate decisions with regard to future maintenance strategies.

Performance can be measured by defining the level of success or failure in terms of schedule, cost and functionality [18, 19]. Since the rising maintenance cost is one of major issues affecting the industry and public, the cost performance is analysed in this research as the dependent variable.

The aspect of the cost or expenditure incurred for building maintenance is most often used for measuring performance of buildings. The maintenance performance is then calculated using the variance of actual expenditures and planned costs for building maintenance activities [20]. The comparison between the actual and planned costs is made to identify the level of maintenance performance. For instance, the maintenance performance of a building system is deemed to be below expectations when the actual spending for maintenance tasks exceeds the planned cost. In contrast, high performance level is achieved when the total expenditure is less than the planned cost for maintenance works.

\section{Research methodology}

This research was conducted using the triangulation approach, which included literature review, questionnaire survey that is recognised as the most appropriate method for data collection, and a semi-structured interview for validation of quantitative results. Characteristics of scheduled maintenance were identified by reviewing journal articles and other reliable reference sources. Then a simple random sampling was adopted in questionnaire survey to identify relevant respondents who have been or are currently involved in office building maintenance management. These respondents were the building manager, building supervisor or executive, technician, and others. Thirty-three percent of valid return questionnaires, with reliable and accurate results, were obtained from the studied population. In order to validate the questionnaire results, experienced building managers were interviewed. Semistructured interviews were conducted to obtain further details and to gather an in-depth understanding of characteristics of scheduled maintenance. Indeed, the interview session reached saturation without new information after 15 respondents were interviewed. Thus, answers or responses formulated by the respondents were similar and predictable.

It is important to ensure that the data used in a study are reliable. Generally, the reliability of data can be established by testing the consistency and stability [21]. In social 
science research, Cronbach's alpha is widely used to test the reliability of data. This measure indicates the consistency of data. In other words, it is computed in terms of average inter-correlations among the items measuring the outcome. The Cronbach's alpha coefficient can easily be computed and obtained by using the Statistical Package for Social Science (SPSS) software. The alpha that reflects acceptable reliability should be above 0.70 .

A correlation test was used to measure the relationship between characteristics of maintenance strategy and performance through SPSS [22]. In this study, the Pearson product-moment correlation was used in the analysis. It is a statistic correlation designed to measure the strength of a supposed linear association between two variables [23]. In general terms, a correlation coefficient of -1.00 or +1.00 is a perfect negative or positive relationship, respectively. A correlation coefficient of zero means that no linear relationship exists. In fact, the correlation coefficient indicates the strength of the linear relationship between two variables [24]. In a research, a correlation coefficient of less than 0.3 points to a weak relationship; a coefficient of 0.3 to 0.5 denotes a moderate relationship; and a correlation coefficient of 0.5 or more points to a strong relationship between two variables $[23,24]$. Thus, it was expected to obtain the correlation coefficient of 0.3 or above to demonstrate the strength of relationships between the variables. Meanwhile, it is important to test the significance of the relationships. The $p$-value of less than 0.05 is required to indicate that relationships are statistically significant [24]. Therefore, the significant relationship between variables in this study could be determined if both criteria are met.

The findings about relationships between characteristics of scheduled maintenance and cost performance were analysed to obtain information for the prediction of maintenance performance. The prediction of the value of a dependent variable from the value of an independent variable is called regression [25]. More than 1 significant independent variable was identified in this study. Thus, multiple regression was used as it is a method for analysing collective and separate contributions of two or more independent variables to the variation of a dependent variable. In regression analysis, the coefficient of determination assesses the strength of relationship between the dependent variable and independent variables. It measures the proportion of variation in a dependent variable that can be explained statistically by independent variables [24]. Generally, the multiple linear regression is formulated as:

$$
Y=\beta_{0}+\beta_{1} X_{1}+\beta_{2} X_{2}+\ldots+\beta_{k} X_{k}+\varepsilon
$$

\section{Where}

$\mathrm{Y} \quad$ - is the dependent variable $(\mathrm{Y}=$ maintenance expenditure variance)
$\mathrm{X}_{1}, \mathrm{X}_{2}, \ldots, \mathrm{X}_{\mathrm{k}}$ - are independent variables $\left(\mathrm{X}_{1}=\right.$ skill and knowledge of labour; $X_{2}=$ level of spare part and material stock, ...)

$Y=\beta_{0}+\beta_{1} X_{1}+\beta_{2} X_{2}+\ldots+\beta_{k} X_{k}$ - is the deterministic portion of the model

$\beta_{\mathrm{i}}$ - determines the contribution of the independent variable $X$

$\varepsilon \quad$ - is a random error.

\section{Findings and discussions}

In this research, the number of valid return questionnaires was 133 , which is 33 per cent of the total research population. Thus, the results were able to represent the research population.

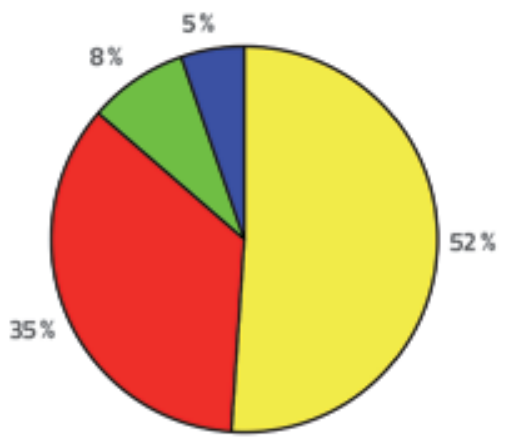

$\square$ Building Manager

Q Building Executive/ Supervisor

口 Building Technician

Others

Figure 1. Respondents' profile

Figure 1 shows that the respondents to the questionnaire survey comprised building managers, building executives or supervisors, building technicians, and others. Based on the data obtained during the survey, some of the respondents, included in the category of "others", were either managing directors of a property management firm, or mechanical and electrical engineers. More than 85 percent of the respondents were building managers, executives, and supervisors. They have considerable expertise in the planning and implementation of maintenance strategies.

Then, the reliability analysis was performed for the characteristics of scheduled maintenance to test the reliability of data collected during the survey. The Cronbach's alpha coefficient for characteristics of scheduled maintenance amounted to 0.741 , which means that the scale and data obtained were quite reliable.

\subsection{Relationship between characteristics of scheduled maintenance and cost performance}

The relationship between characteristics of scheduled maintenance and cost performance was identified as shown in Table 1. The cost performance was the dependent variable in this study, which was determined by maintenance expenditure variance. In addition, the total of six independent variables were used in this study. Among the six of them, five were found to be significantly correlated to the maintenance expenditure variance: 
- Skill and knowledge of labour

- Level of spare part and material stock

- Quality of spare parts and materials

- Length of predetermined maintenance interval

- Amount of maintenance and failure downtime

Table 1. Correlation between characteristics of scheduled maintenance and maintenance cost performance

\begin{tabular}{|l|c|}
\hline Characteristics of scheduled maintenance & $\begin{array}{c}\text { Maintenance } \\
\text { Expenditure Variance }\end{array}$ \\
\hline Skilled Labour - Skill and Knowledge & $-0,643^{* *}$ \\
\hline Skilled Labour - Number of Labours & $-0,111$ \\
\hline Spare Parts and Materials - Level of Stock & $-0,366^{* *}$ \\
\hline Spare Parts and Materials - Quality & $-0,636^{* *}$ \\
\hline $\begin{array}{l}\text { Predetermined Maintenance Interval - } \\
\text { Length of Interval }\end{array}$ & $-0,554^{* *}$ \\
\hline $\begin{array}{l}\text { Failure and Maintenance Downtime - } \\
\text { Amount of Downtime }\end{array}$ & $-0,369^{* *}$ \\
\hline $\begin{array}{l}* * \\
*\end{array}$ & Correlation is significant at the 0.01 level (2-tailed) \\
\hline
\end{tabular}

In scheduled maintenance, the quality of work provided by the maintenance labour directly influences the maintenance performance outcomes [11]. This statement is confirmed by the analysis result. According to the correlation analysis results obtained as shown in Table 1, the skill and knowledge of maintenance labour is significantly correlated to the maintenance expenditure variance. In addition, the majority of respondents who participated in interview sessions confirmed that a skilled and knowledgeable technician is able to perform maintenance tasks with a minimum error. They further explained that this would avoid additional expenditures due to mistakes or errors in the conduct of maintenance activities. In fact, the labour without proper skill and knowledge is more likely to misjudge and misinterpret the condition or problem in the system. The repair and replacement works done by such labour might not be appropriate. As a result, further damage will occur and additional repair works will be required. Consequently, an additional maintenance cost will be incurred to realize the task, and the maintenance budget will be exceeded.

The level of spare part and material stock is an another highly significant aspect in scheduled maintenance. A greater amount of spare parts is needed to replace the existing parts compared to other maintenance strategies. In this research, the level of spare part and material stock was found to be significantly correlated to the maintenance expenditure variance (see Table 1). The analysis result supports the statement that accurate spare parts identification and stocking helps to control and reduce the operation and maintenance costs [12]. For instance, most of the interviewees claimed that the maintenance personnel will be compelled to order small amounts of spare parts to execute the maintenance works, when no adequate spare part stock is available. It is usually more expensive to order a small amount of spare parts instead of a larger amount. As a result, the variance of maintenance expenditure occurs. Therefore, the interviewees admitted that an adequate level of spare part stock enables them to avoid ad-hoc requisition of spare parts, which is always more costly. Furthermore, the analysis results support the statement that the quality of spare parts and materials always influences performance or efficiency of maintenance activities [13]. The results show that the quality of spare parts and the maintenance expenditure variance are significantly correlated (see Table 1). This confirms the statement that good quality spare parts and materials can optimise maintenance expenditures [26]. The respondents of interview sessions also commented that good quality spare parts have longer lifespan, which minimises defects and the need for maintenance. On the other hand, poor quality spare parts and materials are likely to cause damage and unwanted failure to building systems. Thus, additional repair and replacement works are required. Extra maintenance expenditure is needed and variance of maintenance expenditure occurs.

Meanwhile, the length of the predetermined maintenance interval is a vital aspect that has to be given a proper significance in scheduled maintenance. The length of a fixed maintenance interval was significantly correlated to the maintenance expenditure variance (see Table 1). The correlation analysis result proves that the delay or absence of maintenance work at the right time, may cause further damage or defects to the system components [14]. In this respect, additional repair and replacement costs are required to restore the system back to its acceptable operation standard. Thus, an optimum maintenance interval must be defined. Although frequent maintenance can enhance the quality of a system, it will also boost maintenance costs [27]. Hence, the interviewees suggested that the maintenance interval planning must be based on the priority of services and level of harm to human beings.

In addition, proper downtime planning is necessary to retain and improve the maintenance performance. The amount of failure and maintenance downtimes was significantly correlated to the maintenance expenditure variance (see Table 1). The statement that the downtime might be very costly was confirmed [2]. On top of that, the majority of interview participants revealed that extended maintenance or failure downtime is likely to affect the productivity of building users. Actually, the maintenance expenditure is likely to be varied as more downtimes occur in a building system. Therefore, the downtime for maintenance must be well managed to avoid unnecessary costs. The objective is therefore to achieve minimum failure and maintenance downtimes in building maintenance. 
Table 2. Checking assumption of Model 1 (Enter Method)

\begin{tabular}{|l|c|c|}
\hline Variable & $\begin{array}{c}\text { Collinearity tolerance } \\
(>0.1)\end{array}$ & $\begin{array}{c}\text { Variance inflation factor } \\
(<10)\end{array}$ \\
\hline Skill and knowledge of labour & 0,489 \\
\hline Level of spare part and material stock & 0,808 \\
\hline Quality of spare parts and materials & 0,500 & 1,238 \\
\hline Length of predetermined maintenance interval & 0,672 & 2,002 \\
\hline Amount of maintenance and failure downtime & 0,785 & 1,489 \\
\hline
\end{tabular}

Table 3. Checking assumption of Model 2 (Stepwise Method)

\begin{tabular}{|c|c|c|}
\hline Variable & $\begin{array}{l}\text { Collinearity tolerance } \\
\qquad(>0.1)\end{array}$ & $\begin{array}{l}\text { Variance inflation factor } \\
\qquad(<10)\end{array}$ \\
\hline Skill and knowledge of labour & 0,541 & 1,848 \\
\hline Quality of spare parts and materials & 0,537 & 1,861 \\
\hline Length of predetermined maintenance interval & 0,675 & 1,481 \\
\hline
\end{tabular}

\subsection{Prediction model for maintenance cost performance}

Since it was established that five characteristics are significantly correlated to the cost performance, the predictors of maintenance expenditure variance (MEV) included skill and knowledge of labour (SKL), level of spare part and material stock (LSP), quality of spare parts and materials (QSP), length of predetermined maintenance interval (LMI), as well as amount of maintenance and failure downtime (AMD). The regression model for the research was produced as follows:

\section{Model 1(Enter Method)}

MEV $=7.704-0.380$ SKL -0.144 LSP -0.361 QSP -0.317 LMI - 0.085 AMD

Coefficient of multiple regression, $\mathrm{R}^{2}=0.540(54,0 \%)$.

However, the analysis results have revealed that two predictors were not significant with $\mathrm{p}$-value of more than 0.05 . This is why an another regression model was produced to eliminate the non-significant predictors:

\section{Model 2 (Stepwise Method)}

\section{$\mathrm{MEV}=7.286-0.423 \mathrm{SKL}-0.400 \mathrm{QSP}-0.324 \mathrm{LMI}$}

Coefficient of multiple regression, $\mathrm{R}^{2}=0.532(53,2 \%)$.

In order to ensure that the regression models were appropriate, the validity of the regression models was checked. Data presented in Table 2 and Table 3 prove that multi-collinearity problems were not registered for Model 1 and Model 2, respectively. Thus, the tolerance value should not be less than 0.1 and the variance inflation factor, VIF should not be greater than 10 [24].
In Model 2, three characteristics were identified as significant predictors of the maintenance expenditure variance. These characteristics are: skill and knowledge of labour, quality of spare parts and materials, and length of the predetermined maintenance interval. In fact, 53.2 percent maintenance expenditure variations can be predicted by the three significant predictors. Thus, these characteristics must be taken into consideration when planning and implementing the maintenance program. If proper attention is paid to these characteristics, the maintenance cost performance would most likely be improved.

\section{Conclusion}

The significance of planning and executing an appropriate maintenance strategy to improve maintenance performance is emphasized in this paper. The analysis of relevant literature has revealed that the cost performance is directly influenced by characteristics of scheduled maintenance. Therefore, it is important to understand the influence of characteristics throughout the maintenance process, from planning to the outcome of maintenance activities. According to literature data, six scheduled maintenance characteristics are dominant and important for maintenance performance. Among the six characteristics, five were determined to be significantly correlated to the maintenance expenditure variance. These are the skill and knowledge of labour, level of spare part and material stock, quality of spare parts and materials, length of predetermined maintenance interval, and the amount of maintenance and failure downtime. In addition, two prediction models were generated using the SPSS. Two of the independent variables given in Model 1 were determined to be insignificant predictors. Thus, an another model was produced using the Stepwise method. As a result, only three independent variables were selected by SPSS in Model 2, which was more significant 
compared to Model 1. The significant predictors included skill and knowledge of labour, quality of spare parts and materials, and the length of predetermined maintenance interval. This paper is aimed at assisting practitioners in considering and taking into account significant characteristics in the scope of planning and implementation of scheduled maintenance activities, with an emphasis on an optimum maintenance cost performance.

\section{Acknowledgement}

The authors gratefully acknowledge the financial support of the University of Malaya Research Grant (UMRG), grant no RP007A/13SUS established at the University of Malaya, Sustainability Science Research Cluster.

\section{REFERENCES}

[1] Seeley, I. H.: Building Maintenance. Palgrave, New York, 1987.

[2] Chareonsuk, C., Nagarur, N. and Tabycanon, M. T.: A Multicriteria Approach to the Selection of Preventive Maintenance Intervals. International Journal of Production Economics, 49 (1997), pp. 5564.

[3] Horner, R.M., El-Haram, M.A., Munns, A.: Building Maintenance Strategy: A New Management Approach. International Journal of Quality in Maintenance, 3 (1997) 4, pp. 273-280.

[4] DBKL Jawatankuasa Perancang Bandar 1986. Dewan Bandaraya Kuala Lumpur, City, 1986.

[5] Zawawi, E.M.A., Kamaruzzaman, S.N.: Personnel Characteristics of Maintenance Practice: A Case of High-Rise Office Buildings in Malaysia. Journal of Sustainable Development, 2 (2009) 1, pp. 111-116.

[6] Myeda, N.E., Kamaruzzaman, S.N., Pitt, M.: Measuring the Performance of Office Buildings Maintenance Management in Malaysia. Journal of Facilities Management, 9 (2011) 3, pp. 181 199.

[7] Halim, T., Muthusamy, K., Chia, S.Y., Lam, S.W.: A Systems Approach in the Evaluation and Comparison of Engineering Services Applied in Facilities Management. Facilities, 29 (2011) 3/4, pp. 114-132.

[8] Flores-Colen, I., De Brito, J.: A Systematic Approach for Maintenance Budgeting of Buildings Facades Based on Predictive and Preventive Strategies. Construction and Building Materials, 24 (2010), pp. 1718-1729.

[9] Nilsson, J.: Reliability and Cost Centered Maintenance Methods: Nuclear Power and Reliability Centered Maintenance (RCM). Maintenance Management in Power Systems (2007).

[10] Hameed, Z., Ahn, S.H., Cho, Y.M.: Practical Aspects of a Condition Monitoring System for a Wind Turbine with Emphasis on its Design, System Architecture, Testing and Installation. Renewable Energy, 35 (2010), pp. 879-894.

[11] Groote, P. D.: Maintenance Performance Analysis: A Practical Approach. Journal of Quality in Maintenance Engineering, 1 (1995) 2, pp. 4-24.

[12] Tsang, A. H. C.: Condition-Based Maintenance: Tools and Decision Making Journal of Quality in Maintenance Engineering, 1 (1995) 3, pp. 3-17.
[13] Ali, A.S., Kamaruzzaman, S.N., Sulaiman, R., Au Yong, C.P.: Factors Affecting Housing Maintenance Cost in Malaysia. Journal of Facilities Management, 8 (2010) 4, pp. 285-298.

[14] Narayan, V.: Effective Maintenance Management: Risk and Reliability Strategies for Optimizing Performance. Industrial Press Inc, New York, 2003.

[15] Yang, S.K.: A Condition-Based Preventive Maintenance Arrangement for Thermal Power Plants. Electric Power Systems Research, 72 (2004), pp. 49-62.

[16] Zuashkiani, A., Rahmandad, H., Jardine, A.K.S.: Mapping the Dynamics of Overall Equipment Effectiveness to Enhance Asset Management Practices. Journal of Quality in Maintenance Engineering, 17 (2011) 1, pp. 74-92.

[17] Amaratunga, D., Baldry, D.: Moving from Performance Measurement to Performance Management. Facilities, 20 (2002) 5/6, pp. 217-223.

[18] Johnson, J.: Choas: The Dollar Drain of IT Project Failures. Application Development Trend, 2 (1995), pp. 41-47.

[19] Sidwell, A.C.: Project Management: Dynamics and Performance. Journal of Construction Management and Economics, 8 (1990), pp. 159-178.

[20] Ali, A.S.: Cost Decision Making in Building Maintenance Practice in Malaysia. Journal of Facilities Management, 7 (2009) 4, pp. 298-306.

[21] Leech, N.L., Barrett, K.C., Morgan, G.A.: IBM SPSS for Intermediate Statistics: Use and Interpretation. Taylor and Francis Group, LLC, New York, 2011.

[22] Diamond, I., Jefferies, J.: Beginning Statistics: An Introduction for Social Scientists. SAGE Publications Ltd, London, 2006.

[23] Gray, C.D., Kinnear, P.R.: IBM SPSS Statistics 19 Made Simple. Pyschology Press, East Sussex, 2012.

[24] Saunders, M., Lewis, P., Thornhill, A.: Research Methods for Business Students. Pearson Education Limited, Essex, 2009.

[25] Graziano, A.M., Raulin, M.L.: Research Methods: A Process of Inquiry. Pearson Education Inc, Boston, 2010.

[26] De Silva, N., Ranasinghe, M.: Maintainability Risks of Condominiums in Sri Lanka. Journal of Financial Management of Property and Construction, 15 (2010) 1, pp. 41-60.

[27] Moghaddam, K.S., Usher, J.S.: Optimal Preventive Maintenance and Replacement Schedules with Variable Improvement Factor. Journal of Quality in Maintenance Engineering, 16 (2010) 3, pp. 271-287. 